New materials

\title{
Japan set to come out winner
}

\section{Washington}

JAPAN, not the United States, will capture the large new market for advanced ceramics and composites according to a new study* from the US Office of Technology Assessment (OTA). The study pulls no punches in blaming US industry for failing to match Japan's well-coordinated effort to develop and commercialize advanced materials technologies.

Much of the initial research that demonstrated the feasibility of new highperformance materials was done in the United States but foreign industry and industry-government teams, especially in Japan, have "far more aggressive programmes to commercialize near-term applications" says OTA.

Advanced ceramics, such as those based on silicon carbide/nitride or zirconium oxide, with their inherent advantages of lightness, strength and temperature resistance, have the potential to replace metals in many engineering applications. According to Congress's research office, the potential will be realized only when the design of the materials and the structures they are used in become integrated, as yet not possible on a large scale.

The federal government will spend $\$ 60$ million this year on research in this field, But industry has been slow to follow up on even non-military federal research, according to OTA, and industrial investment must be encouraged. Commercialization of military research, accounting for about one half of the federal outlay, is further inhibited by restrictions on publication of research results and on exports.

The size of the US market for ceramics in the year 2,000 is estimated at between $\$ 1,000$ million and $\$ 5,000$ million. By way of comparison, the world market in 1983 was only $\$ 250$ million. The main applications will be in bearings, heat exchangers, and automobile engine components; in the longer term they may be used in advanced engines, if some major technical

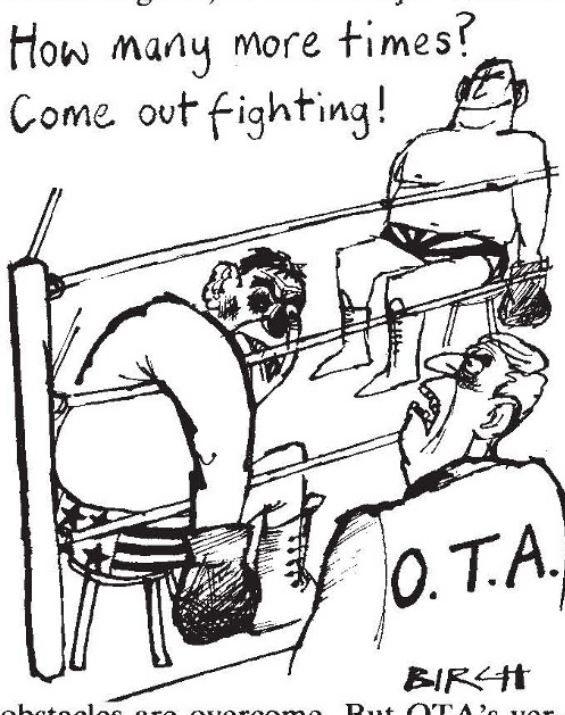

obstacles are overcome. But O'TA's verdict is that US industry considers the risks to be too high to conduct the necessary long-term research, and that more federal efforts are necessary. The priorities should include materials processing, reliability and durability in different chemical and physical environments, and tribology, testing and joining.

Tim Beardsley

* New structural materials technologies: opportunities for use of advanced ceramics and composites. Office of Technology Assessment, 1986.

\section{Resignation provokes criticism}

Washington

Whatever the real extent of the blow to the $X$-ray laser programme at Lawrence Livermore laboratory caused by the resignation last week of Peter Hagelstein, the physicist credited with performing the basic theoretical calculations for the device, press attention could not have been less welcome to the administration.

The nuclear pumped $X$-ray laser is the most controversial item of the Strategic Defense Initiative (SDI), since its use would seem to require nuclear explosions in space. Next year's budget for SDI, of which the $\mathrm{X}$-ray laser programme is a key part, has still to be decided by Congress but may be very much less than the $\$ \mathbf{5 , 3 0 0}$ million requested by President Reagan.

Hagelstein, who will take up a post as associate professor at Massachusetts Institute of Technology (MIT) in October, has not told the reasons for his departure, and it was speculated that he had become disen- chanted with the military application of his work. The story of how Hagelstein left MIT, to take advantage of powerful equipment for investigating $X$-ray lasing at Livermore, has been told by William Broad of the New York Times in his book "Star Warriors". Broad wrote that Hagelstein originally wanted the $\mathrm{X}$-ray laser to be used for medical research and that he felt he had his "arm twisted" into doing weapons research.

But according to Professor Richard Adler of MIT, associate head of the department of electrical engineering and computer science and a personal friend of Hagelstein, his decision to return to MIT was perhaps simply a reaction against the "mission oriented, driven" life in a defense research laboratory. Hagelstein will do work on computational physics in the department, probably concentrating on the problem of how to build a laboratoryscale X-ray laser.
Tim Beardsley
Nuclear power

\section{Accident close to the border}

\section{Hamburg}

AN operator error at the just-completed French nuclear power plant at Cattenom has provoked a storm of protest in Luxembourg and West Germany. During a test run of a part of the plant, located near the border with Luxembourg and Saarland, more than 400,000 tonnes of cooling water swamped the cellars, seeped into the soil and flowed under ground below the village of Cattenom back to the Mosel river.

The water contained little or no fission products. But critics, took offence at the behaviour of the plant's operator, Electricité de France (EdF), which, a day and a half after the accident, said that only 8 tonnes of water were lost.

While Jo Leinen (Social Democrat), environment minister of the Saarland, reproached France for "making all the mistakes that could be made", Le Monde accused the Germans of reacting hysterically. Leinen has already criticised the design of the Cattenom plant saying that the quality of its steel and concrete is not high enough and that it lacks a steel dome to protect the reactors from an aeroplane crash, although there is much air traffic in the area.

The Governments of the Saarland and of ten towns and local districts, along with Luxembourg, have now opened proceedings at the Administrative Court in Strasbourg, to try to defer the start up. At a hearing on September 6 the plaintiffs' hopes were raised when the French state commissioner Antoine Mendras, accepted two of their seven objections: that the EdF built four 1,300 megawatt blocks, although it only had the permission to build two 900 and two 1,300 megawatt blocks; and that it did not inform the EG commission of its plans to discharge radioactive fluids into the Mosel river, although obliged to do so according to article 37 of the Euratom agreement. But on the 8th of September the court ruled not to cancel the permission for operation. All parties represented in the Saarland parliament protested against the judgement.

The German Federal Government is now placed in a difficult situation. Chancellor Helmut Kohl and his environment minister Walter Wallmann (both Christian Democrats) would like to polish up their images by making the French government improve safety standards - French plants are permitted to release five times more radioactivity than German ones. But Wallmann realizes from his July visit to Paris that the French do not appreciate criticism of their energy policies.

The Greens in the federal Government are now demanding Wallmann's resignation.
Claus P. Dechau 